\title{
The Meaning of Prosocial Action for Activists of Legal Assistance Organizations (OBH) in Poor Communities in the City of Palangka Raya
}

\author{
Laila Rahmawati $^{1}$, Ishomuddin ${ }^{2 *}$, Rinikso Kartono ${ }^{3}$, Wahyudi ${ }^{4}$ \\ ${ }^{1}$ Doctor of Social and Political Sciences, University of Muhammadiyah Malang \\ ${ }^{2}$ Professor of Sociology of Islamic Society, University of Muhammadiyah Malang \\ ${ }^{3}$ Doctor of Social Welfare, University of Muhammadiyah Malang \\ ${ }^{4}$ Doctor of Sociology, University of Muhammadiyah Malang
}

*Corresponding Author: Ishomuddin, Professor of Sociology of Islamic Society, University of Muhammadiyah Malang, Indonesia

\begin{abstract}
This research was conducted on the background of a phenomenon of law enforcement practices that occur in the community, especially those experienced by the poor often giving birth to injustice. The purpose of this study is to examine two main problems namely; (1) to describe the prosocial actions of legal aid activists in Palangka Raya City, and (2) to understand the meaning of prosocial actions of legal aid activists in providing legal assistance in Palangka Raya City. This research was conducted using qualitative methods and carried out naturally. The research subjects were activists of the Legal Stone Organization $(\mathrm{OBH})$ "Palangkaraya Friends of the Law" with data collection techniques through observation, interviews and documentation. In order to obtain more accurate data, the observations are carried out diligently, and strengthened by triangulation, as well as discussions with OBH activists of the SahabatHukum Association. Furthermore, the data obtained were analyzed following qualitative research procedures starting from (1) condensation data, (2) data display, and (3) verifying conclusions. The theory used to explain this research uses the social norm theory (the norm of social responsibility) proposed by Berkowitz. The results of the study found that (1) the existence of social interaction between OBH activists who provide help with clients who are assisted in prosocial actions legal aid activists are related to the norms of social responsibility. It is said to help others is something we must do, whether it does not depend on future rewards nor does that person ever help us. As an advocate there is already a soul of help in providing legal assistance to people with full awareness. Activists also try to be responsible and give an argument that whatever is in the client is ready to face. Activists as advisors and legal advocates of poor clients, have a passion to donate all the resources they have, provide free assistance with probono with sincerity. (2) The meaning of prosocial actions by $O B H$ activists in providing legal assistance. The presence of advocate advocacy also protects the defendant from labeling to ensure the principle of presumption of innocence for the accused. Because it cannot be denied that the sensitivity of public assessment of someone who has been positioned as a defendant raises acts of discrimination and intolerance.
\end{abstract}

Key words: Prosocial actions, OBH Activists, Advocates, Assistance

\section{INTRODUCTION}

Prosocial action starts from social contact, prosocial action is taken and planning is carried out on the grounds of helping people without seeing any supporting motives. Self interest is the motivation of prosocial action by not expecting anything in return or anything for himself. Dedication and sacrifice of those who do and are voluntary or volunteerism that will benefit others rather than profit taking both socially and materially.Basically, in the prosocial actions, empathy seems to have a close relationship with individual prosocial behavior. Individual abilities and empathy are raised in expressing their emotions, so a person can be measured empathy through the group of emotional epistemology, emotional expression, and individual capabilities in laying roles with others. Substantively, empathy is limited to the individual by how he implements his prosocial ideas that he has in his actions or not. (Robert and Strayer, 1986: 2). 
Hurlock (1999: 118) reveals that empathy is an individual's capability in understanding other emotions and feelings and the capability of illustrating oneself at the locus of others. Someone's empathy will be able to become the motor of feelings and behavior in providing assistance to others, especially the poor who face legal cases. There is a personality factor which is the basis of prosocial behavior which is divided into two factors, namely personality and circumstances. Personal traits that influence prosocial behavior are mature emotions. Someone who has emotional maturity, he has the ability to behave well prosocial. Chaplin (1995: 53) defines behavior as someone who experiences everything that includes the response that is seen. Watson (1984: 272) underlines prosocial behavior which has a significant contribution to other individuals, helping behavior is fully driven by something important with no strings attached. Kartono (2003: 180) mentions prosocial action is a social action that takes profit in the form characterized by the parts of cooperation, togetherness, cooperation, and altruism. Contributions arising from prosocial behavior as far as someone's actions related to social interaction. Sears (1991: 61) asserts substantively that each person is not only a single creation that can live independently, but as social creation always becomes dependent on others, one cannot obtain the enjoyment of a happy and happy life without social milieu. individuals are said to behave prosocial when someone is helping others by ignoring the subject's motivation, the behavior arises due to the hardships suffered by other individuals which include exchanging help, comforting each other, saving, sacrifice, generosity, and sharing.

Researchers conducting this study began with concern when they discovered the phenomenon of the rule of law supremacy that occurs in the community, especially vulnerable groups in people who are unable to often lead to powerlessness. Groups of poor people are very vulnerable to the injustice of social groups in the midst of community life. The process of rule of law is believed to give birth to legal injustice. This unfair treatment of law stems from legal operations in a system.

A study written by Sholahudin (2011:25) concerning the rule of law of poor people in the case of a theft of a watermelon farmer who cannot afford; Kholil and Bashar in the City of Kediri, indicated that the supremacy of the law of the apparatus in understanding textual cases was merely "rigid" in accordance with the law, legalistic-positivistic, there was no attempt to understand the case in a sociological perspective. For Imam Sukadi (2011), the danger is that law is not only privileging procedural formal always prioritizing legal certainty. But it must also be able to look comprehensively in various problems that arise in life. In the sense that law is not only limited in the perspective of a rigid (exclusive) rule system but the law in the review of a flexible (inclusive) value order. So, it's not only legal certainty, there will be valuable justice therapy in the community.

A study conducted by BudimanTanuredjo (2010), gives an indication that the law can be distorted and made playful, especially when it befalls the poor. There are many stories of cases when entering the legal cycle, weak people are only pursuing legal-formal, not substantive. Weak individuals have a low vis-a-vis vision with law enforcement professionals who mention articles and have characteristics that utilize those who are not familiar with the law. According to SoetandyoWignyosoebroto, in his work "Grandma Minah not Steal Coklet", (2010), legal justice is the implementation of national law that upholds moral principles based on local wisdom that become living law in their environment. But in another domain, legal action that occurred in the poor in Palangkaraya actually received serious attention for legal aid organizations $(\mathrm{OBH})$. Based on this, the following research problems can be formulated: (1) what are the prosocial actions of activists of legal aid organizations in Palangka Raya City? (2) What is the meaning of prosocial actions of activists of legal aid organizations in providing legal assistance in the City of Palangka Raya?

\section{LITERATURE REVIEW}

Anggita Ersyandi (2017) in her research on prosocial behavior in college students explained that prosocial forms a natural trait attached to human individuals. The nature of helping one another, loving and completing and helping are the reasons why humans then interact with each other to help other humans. With this interaction, humans need other people in order to manifest the prosocial behavior. The purpose of this research is to explore and understand the prosocial behavior of students, which were carried out on 40 activist students and 40 non-activist students in the Faculty of Psychology and the Faculty of Engineering. The method used in this research is descriptive qualitative method. The results of the research that have been done have obtained the result that social norms are the most common cause of prosocial forms of behavior including helping behavior. The reason for 
activist and non-activist students doing prosocial behavior, activist and non-activist students often do prosocial behavior alone, people who are often helped in prosocial behavior on activist and nonactivist students are people who are still in the sphere of friendship with these students.

Research conducted by Ibn Munfaridz takes the title of Prosocial Behavior Differences Against Other Ethnic Groups between Javanese and Buginese (2016) in his research explained that the Indonesian nation is a pluralistic nation that has variants of religious, language, race, culture and ethnic diversity, despite the values Pancasila and BhinekaTunggalka have meanings, although different, but also one. The big tribes in Indonesia are Javanese and Bugis, which have very diverse cultural values. This study portrays whether there is a differentiation of prosocial actions between Javanese and Buginese. The study used 75 Javanese and 75 Bugis subjects with a 21-year age limit. The sampling technique used was purposive sampling where the research subjects were known and in accordance with existing characteristics. Likert scale models are used in data collection. The data analysis method uses the comparative Independent sample t-test. The results showed that the value ( $\mathrm{t}$ count $=1.464$ (sig) 0.05) which means there is no difference in prosocial behavior towards other ethnic groups between the Javanese and the Bugis ethnic groups. Thus, that culture does not affect prosocial behavior.

Other studies conducted by A.A. Gd Putra Sastra Pradnyana and Made Diah Lestari Psychology Study Program, Faculty of Medicine, Udayana University (2016) with the title Role of Prosocial Behavior, Self-Efficacy and Empathy on Employees of the Regional Disaster Management Agency (BPBD) in Bali. Helping is a prosocial action taken by someone against another person. Prosocial action is the main task and inherent function, it is known where BPBD handles in the field of disaster management related to humanitarian work in carrying out work already outlined in Law No. 24 of 2007. To carry out a job that bears risks and challenges, employees must believe that they are capable of applying self-strength based. Individuals who have empathy reinforce the act of helping as a prosocial act. The purpose of the study was to describe the role of prosocial action, confidence, and empathy in the employees of the Regional Disaster Management Agency (BPBD) in Bali. The subjects in this study were BPBD employees with the status of Civil Servants (PNS), with a total of 96 people. The approach used is a quantitative approach. Prosocial behavior scale is a measuring tool used in this study, including self-efficacy scale and empathy scale. The multiple regression analysis method was used in this study.

Prosocial behavior is defined as having alignments with other people whatever the driving force. For Baron\& Byrne (2005) reveals prosocial behavior is an act that brings profit to someone without regard to the profit of the subject who did the act, maybe even the person who helped ignored the risks that they would experience. Gerungan (2000) expresses prosocial actions including actions that provide profit to someone who has a significant contribution to strengthen the values of physical and spiritual benefit.Abraham and Shanley (1997) explain that social and other influences on emergency situations are more likely to cause decisions to help. The opinion of Dayakisni\&Hudaniah (2003) which defines prosocial actions with actions to be able to change behavior both mentally and physically. In terms of material and psychological intensively to make the less good to be good. Based on a number of definitions, prosocial behavior can be defined as actions directed at others, both physically and psychologically that provide positive benefits for the person subjected to the action, even though the act does not actually have clear benefits and advantages for individuals who commit it and the action is carried out in accordance with the prevailing community norms

According to Mussen (1990), found several kinds of prosocial behavioral aspects as follows: (1) Helping, namely the willingness to provide assistance or help to others who are experiencing difficulties, both in the form of moral and material. Helping includes helping others or offering something that supports the activities of others. (2) Sharing (sharing), which is willing to share feelings with others in an atmosphere of joy and sorrow, (3) Cooperation (cooperating), namely the willingness to cooperate with others in order to achieve a goal. Cooperating is usually mutually beneficial, giving, helping and calming. (4) Honest (honesty), namely the willingness to do things as they are, not cheating on others. (5) Donating (donating), namely the willingness to give voluntarily a portion of his belongings to people in need.

Furthermore Staub (1987) states that there are three indicators that become aspects of prosocial behavior, namely (1) The action ends with itself and does not demand profit from the perpetrator. (2) The act was born voluntarily. (3) That action produces goodness. The attitude that is raised in the 
individual always has a background, as well as when someone is doing prosocial behavior. According to Staub in Dayakisni and Hudaniah (2003) factors influencing prosocial behavior, namely: (1) Selfgain: a person hopes to gain or avoid losing something, for example the desire to obtain recognition, praise or fear of exclusion. (2) Personal values and norms: there are social values and norms internalized by individuals during socialization and some of the values and norms are related to prosocial actions, such as the obligation to uphold truth and justice and the existence of reciprocal norms. (3) Empathy: one's ability to share in the feelings or experiences of others.

Sears (1991) suggests several factors that influence prosocial behavior more specifically, including: (1) Situational in the form of involving the presence of people; someone where alone has a tendency to cause a reaction when in an emergency situation than if there are other individuals who are familiar with the situation. The more others come, the fewer people who really help. Because it is known as a bystander effect. Someone who only he sees others encounters difficulties, then that person has the responsibility to fully react in the situation. (2) Environment. Basic environmental conditions also affect the willingness to help such as weather conditions, city size, and the degree of noise. (3) Deadline pressure has a significant effect on helping. Someone forced due to deadlines ignore help given by a helper, including: Personality Factors, namely the existence of certain personality traits that encourage individuals to provide help in some types of situations and not in other situations. For example, individuals have the uniqueness of making donations for the benefit of worship which has a high level of need to be socially acceptable, but only when others witness it. The individual is driven by the desire to get praise from others so that they behave more prosocially only when the action is heeded. Mood, a person is more motivated to provide help if his mood is good, in other words, an atmosphere of positive feelings that can increase the willingness to act prosocial. Guilt; efforts to keep away actions that harm or endanger others and replace them with good actions. An interest in minimizing feelings of guilt can change someone helping individuals who feel disadvantaged. Distress and empathy, personal distress (personal distress) is an individual's personal response to someone's distress, for example shock, fear, anxiety, concern, helplessness, or feel whatever is happening to. Another feeling of empathy (empathic concern) is the feeling of giving attention to someone, especially in sharing knowledge and not neglecting to find solutions to the difficulties of others.

Self-distress is aimed at self-self that is driven to minimize anxiety by giving help to those in need, but can carry it out by ignoring the condition or not caring about the difficulties around them. Based on the descriptions above it can be concluded that the factors that influence prosocial behavior include, Self-gain, Empathy, Personal values and norms, helper, situational, guilt, mood.

\section{Methodology}

\subsection{Research Paradigm}

This study uses a social definition paradigm that is understanding people's understanding of the actions taken based on in-depth interviews and observations made. Therefore, in the paradigm of this social definition in addition to aiming to understand the activist prosocial actions in his life who are always actively interacting in the social life environment of their people. Therefore in the work of Weber (1970), he prefers and focuses on a subjective meaning which is carried out by someone on a social action.

\subsection{Research Approach and Type}

The nature of this research is exploratory by presenting a small number of informants to uncover the problem by choosing a qualitative approach. Exploratory research confirms to be examined by choosing certain themes which according to the author's knowledge have not been studied in depth by other researchers.

Bogdan and Taylor (1992: 21-22) write that qualitative research as a mechanism for obtaining descriptive data both verbally and recorded and observed behavior. In the qualitative approach has a profound achievement of a statement, notes and observations of the behavior of individuals, groups, communities, or certain groups, studies conducted in a comprehensive, not partial, and holistic manner. We mean the term qualitative research as a type of research whose findings are not obtained through statistical procedures or other forms of calculation. (Strauss \& Corbin, 2017: 4). 
The reason for the researchers choosing this qualitative approach is so that researchers can easily obtain data on in-depth and natural depictions of the meaning of prosocial activist actions in conducting legal assistance for the underprivileged. The reason for researchers with this qualitative approach is because 1) the researcher is a key researcher; 2) researchers can interact directly with activists; 3) the data that the researchers get can be easily described because the data is in the form of words; 4) researchers prioritize the implementation process rather than the research results; and 5) researchers prioritize data inductively.Based on the above reasons, researchers can communicate directly with the activist subject under study, regarding prosocial actions. Data and facts from the field findings provide meaning in this study and are also supported by theories related to the formulation of the problem under study. A qualitative approach is considered appropriate for conducting studies on research because the problem that becomes the research problem is that it occurs in activists of legal friends in Palangkaraya city who carry out legal assistance, where the data are described in the form of words in the background of individual activists in depth and holistically (holistically).

Researchers chose this qualitative approach because it essentially tries to observe activists providing legal aid, interact with them naturally and try to understand and seek interpretation of the meaning of why activists take prosocial actions in providing free legal assistance. As for other considerations researchers do in research using a qualitative approach as stated by Strauss and Corbin, namely the qualitative method can be used to uncover and understand something behind a phenomenon that is not yet known (Strauss and Corbin, 2017: 5).

\subsection{Data Analysis}

The process of data analysis in this study was carried out continuously from the beginning to the end of the study, both researchers were still in the field and outside the field. Data analysis in the field includes providing codes and temporary interpretations of various information obtained at each step of the research activity. Besides that, data analysis is also carried out outside the field for prosocial activists in Palangka Raya which is a continuation and analysis of data in the field, carried out in full to all data collected, whether through observation, interviews, or documentation.

In carrying out the process of data analysis in this study for prosocial activists carried out continuously from the beginning until the end of the study. The process of data analysis by researchers in this study basically refers to the qualitative research procedures proposed by Miles, Hubennan and Saldana, (2014: 8-10), with the following steps:

\subsubsection{Data Condensation}

At this stage the research activity is the existing data the researcher has analyzed further and refined the existing data as well as sifting through all data obtained and field notes obtained from prosocial activists both data obtained from observations, interviews and documentation in the form description or report. Information data that has been recorded from prosocial activists in the form of field notes is sorted, recapitulated, and analyzed based on the classification of concepts, categories and themes studied. Study the researchers' data to do with the aim to find the main things that the researchers consider important with regard to the research problem.

Furthermore, what if the data obtained is considered still lacking, the researcher returns to the informant to complete it until the researcher considers the data sufficient. The research activities conducted condensation of this data by reviewing all data obtained from prosocial activists in the form of notes, analyzing, sorting out and refining all field notes obtained by prosocial activists will make it easier for researchers to conduct analysis in the next steps.

\subsubsection{Data Display}

At the stage of the appearance of the data or data display is a continuation of data condensation, where at this stage the main problems are then summarized and arranged more systematically, so that the data obtained from the field can be easily described in general as a whole, or only to look at certain parts in research data. By looking at the presentations we will be able to understand what is happening 
and what needs to be done to further analyze or take action based on the understanding gained from the presentations. (Miles, Huberman, and Saldana, 2014).

The data appearance was carried out based on the aspects that were examined, and the data presented from prosocial activists in the form of tabulations were then presented in the form of descriptions and interpretations in accordance with the data obtained. Everything was designed to combine information that is arranged in a comprehensive form and easy to see again, so researchers can master the data obtained. This method is carried out by researchers in order to master and understand research results easily. Appearance of data obtained from this prosocial activist researchers are described in full in the field data exposure and researchers present in the next chapter

\subsubsection{Verifying and Conclusions}

At this stage, the researcher conducted it to draw a conclusion with the aim to fully describe the actual situation and the efforts of the researcher to find meaning from the results of the analysis of research data conducted from the beginning to the end. Conclusion is a step forward from the presentation of data (data display), with an emphasis on the meaning of all the information that researchers find in the field whether the results of interviews from Prosocial activists in the City of Palangka Raya, observations or from the results of documentation. Presentation of data, and drawing conclusions / verification as something intertwined at the time before, during, and after data collection in parallel forms, to build a general interview called "analysis". (Miles, Hubennan and Saldana, 2014).

Withdrawing conclusions researchers do not just quickly draw conclusions of information, but researchers also seek to dig deeper information, for that interim conclusions formulated are still being verified over and over again so that at the end it can produce final conclusions. Overall the flow of the data analysis of this study, the researchers carried out simultaneously / simultaneously and follow the procedures in qualitative research as stated by Miles, Huberman and Saldana, (2014) starting from 1) condensation data; 2) data display; and 3) describe and verify conclusions. The data analysis procedure as stated above, is as shown below:

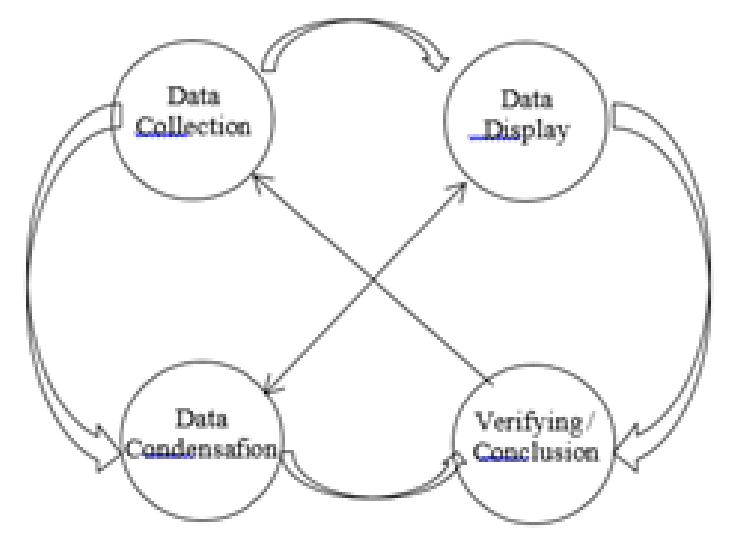

Component: data analysis: Interaktif Model

\section{Results and Discussions}

At the end of this research report, the general conclusions drawn are based on the discussion of research results. Conclusions that are directly related to this research which are used as the basis for answering problems that are directly related to the study of the meaning of prosocial activist prosocial actions in relation to legal assistance for disadvantaged people, then a conclusion can be drawn as follows.

Prosocial actions of activists of legal aid organizations in Palangka Raya City are seen in terms of: Helping, as an advocate, there is a spirit of helping in providing legal assistance to people with full awareness even though they are paid by the state or not paid by the state. Advocates continue to provide assistance or provide advice law through probono that is the sincerity of providing legal assistance at no cost through the Posbakum container. Work handling cases without cost and doing on the basis of awareness, these proposocial activist friends are, on average, victims, then resolve the problem, joining prosocial activists to help others. 
Sharing, the problems that exist in the client must be informed objectively in order to bring up solutions that are truly fair and can give peace to the client. Advocates also try to be responsible and argue that whatever is in the client is ready to face and give an answer if there is a third party who tries to ask for information.

Cooperation. Advocates who are under the auspices of $\mathrm{OBH}$ also collaborate with other $\mathrm{OBH}$ in the geographical and workplace environment where the $\mathrm{OBH}$ is located. This is very reasonable because between $\mathrm{OBH}$ has the same goals and objectives to be able to access government programs and in reporting requires horizontal coordination. The existence of an advocate cannot be separated from his role in working with clients in completing clients' cases where issues are related to administrative issues.

Donating. Advocates as advisors and legal counsel clients who can not afford, have the passion to donate all the resources they have. Not only consider the state-owned budget (prodeo) but furthermore provide free assistance on a probono basis with sincerity.

To be honest (honesty), the community is very difficult to share information and problems they experience, so $\mathrm{OBH}$ activists make programs directly go to the field to clearly know the legal dispute both civil and criminal, then the issues that arise are the issue of unregistered marriage and early marriage. But it is very impossible for poor people to come directly to the Religious Courts and District Courts that have been provided by the government. Without the OBH management who came down to directly pick up. The meaning of prosocial action activists of legal aid organizations in providing legal assistance in the City of Palangka Raya.

Human values (Humanity Values). Basically the Court Legal Aid Post is not merely a forum or room for $\mathrm{OBH}$ activists to provide legal assistance free of charge to people who are unable and do not understand the law, but also to perform other social functions that refer to the upholding of democratic rule of law values and respect for human rights. Legal assistance for the poor and those who do not know the law in criminal cases can certainly make it easier to achieve justice because it makes it easier for businesses such as the maintenance of a grassroots-based justice system because people are assisted to be made aware of the law and understand the law so that they can criticize existing legal products .

Understanding. The Legal Aid Provider can play an active role in explaining and making the legal aid recipient understand the rights, limitations and what is useful for the client to ask for judicial relief from the panel of judges. Practicing advocate skills in the aspect of understanding, namely conducting guidance and direction.

Voluntary (Inventory Enhancement). The research findings in this section can be seen that the establishment of $\mathrm{OBH}$ has consequences with "free" labeling. In substance when establishing $\mathrm{OBH}$, there is already an intention and later it will be implemented in the real actions of activists in helping clients on the basis of willingness or borrowing the term legal aid called probono. Activists do not discriminate treatment, paid or not by the state or client.Social relations, the low access of the poor and marginalized groups to the settlement mechanism due to disputes results in weak supervision of the course of the process of resolving problems / legal disputes, both resolved through formal and non formal legal mechanisms. Communities need access (Access for justice) as recipients of legal assistance, therefore the community needs knowledge about the types of legal aid services. Advocate assistance in the case of criminal cases also provides legal aid services free of charge for people who want to do legal consultation or need assistance in the preparation of legal drafting. The Palangkaraya District Court Legal Aid Post is not only focused on providing free legal aid services for litigation, but also provides non-litigation legal assistance services. Because in principle, the Legal Aid Post must play an active role in raising awareness, obedience, and community compliance with the law so as to create better human resources.

Career. The code of ethics is a moral design formed from binding associations for members. In the code of ethics there are moral professional guidelines. If it violates, a professional association will be sentenced after the special trial. In this case the profession is an advocate. Advocate's code of ethics is intended to control morale or a type of behavioral control that has sanctions more focused both psychiatric and institutional. Acts of work violations, can not only be prosecuted by existing laws (if there are types and models of irregularities), they can also be prosecuted in terms of morality based on 
a code of ethics. Intended as a reference to moral control or a kind of supervision of behavior that sanctions are more concentrated psychologically and institutionally. Professional perpetrators who violate, in addition to being accountable for by the provisions of the applicable legislation (if there are indications that can indicate the type and mode of violation), also can be morally accountable based on the professional code of ethics.

Protective, one of the things experienced by Legal Aid Organization advocates is that many people are still unaware of the existence of Legal Aid Posts at the Courts that provide free legal aid services. So that the people in this case criminal cases have a sense of doubt to openly ask for legal assistance at the Court Legal Aid Post. The public has been indoctrinated that to ask for legal assistance from advocates must pay. Because of these conditions the community is inadequate and their courage to use what is due through legal channels, in other words there is no courage to use legal aid services. In fact, the presence of this Legal Aid Post makes it easier for people who are unable to file a criminal case in the Court to gain access to justice and fulfill their rights as citizens, even though their position is a free defendant.

\section{Conclusion}

After analyzing the findings and conclusions of the research results as what was stated in the previous description, academically for the development of social science, especially in case studies or the meaning of prosH activist prosocial actions, there are two main problems in this implication, are the implications that have to do with social norms theory, and practical implications related to research findings in the field. The two implications can be described as follows.

Implications of social norm theory in the meaning of OBH activist actions. The findings of this research conducted in Palangkaraya City despite the differences in existing theories, but at least support some of the theories that already exist that relate to the meaning of OBH activist actions, especially regarding the theory of volunteering functions inventory put forward by Clary et.al . in Mercer and Debbie (2010: 101) developing volunteering functions inventory (VFI) in six dimensions, as follows; Values. To express or act in important values (Example: humanitarianism). Understanding. To learn more about the world or practice skills that are often not used. Inventory enhancement to enhance and develop personal psychology (Example: engaging in voluntary activities). Social. To strengthen social relations. Career. To get career-related experience. Protective. To reduce negative feelings (Example: guilt, loneliness) or to overcome personal problems.

From the results of this study a theory can be built basically that "human values in the form of values of justice and social welfare, understanding, code of ethics, and avoiding negative things is the meaning of the prosocial actions of $\mathrm{OBH}$ activists in conducting legal assistance to the poor.

So by volunteering the inventory functions of $\mathrm{OBH}$ activists in providing legal assistance to the underprivileged people, they are still carried out to a professional standard.

\section{REFERENCES}

[1] Abdurrahman. 1983. Aspek-AspekBantuanHukum Di Indonesia, Yogyakarta: Cendana Press,

[2] Aditomo, A. danRetnowati S. 2004. HargaDiri, Harga Diridan Kecenderungan Depresipada Remaja Akhir. JurnalPsikologi. No. 1, 1 15.2003.

[3] Ali, Achmad. 2009. MenguakTeoriHukumdanTeoriPeradilan. Jakarta: Kencana.

[4] Alpay. E. 2018. Self Concept and Self Esteem, file:///C:/Users/Pascasarjana/ Downloads/[Alpay]_Self Concept_and_Self-Esteem_in_Children_a(BookFi).pdf

[5] Andrisman. 2007. HukumPidana Azas-Azas danDasarAturanHukumPidana Indonesia, UNILA, Bandar Lampung.

[6] Baron dan Byrne, D. 2005. Social Psychological Understanding Behaviour. Massachusselts: Allyn and Bacon, lnc.

[7] Berzonsky, D.M. 1986. Adolescent Development.London: McMillan Publishers.

[8] Burns, Robert B. 1996. Self Concept Developmental and Education. London: Rinehart and Winston,co.

[9] Creswell, W. John. 2017 Research Desain, PendekatanMetodeKualitatif, KuantitatifdanCampuran. (Terjemahan Achmad Fawaiddan Rianayati Kusmini Pancasari). Yogyakarta: PustakaPelajar.

[10] Dayaksini, T danHudaniah. 2003. Buku I PsikologiPrososial (EdisiRevisi). Malang: UMM Press. 
The Meaning of Prosocial Action for Activists of Legal Assistance Organizations (OBH) in Poor Communities in the City of Palangka Raya

[11] Diekmann Kristina A., et.al. 2001. The Effect of Physical, Psychological, and Social Distance on Fairness Perceptions and Prosocial Behaviors, IACM Conference Proceedings June, 24-27.

[12] Eissenberg, N. Mussen, Paul Henry. 2003. The Roots of Prosocial Behavior in Children. USA: Cambridge University Press.

[13] Fauzan, M. 2005. Pokok-PokokHukum Acara PerdataPeradilan Agama danMhkamahSyari'yah di Indonesia. Jakarta: Kencana.

[14] Gerungan, W.A. 1996, PsikologiSosial, Bandung, Eresco.

[15] Giddens,A,. 2010. MetodeSosiologi: Kaidah-KaidahBaru, Yogyakarta: PustakaPelajar,.

[16] Giddens.AdanTurner.J. (1987) Social Theory Today, DiterjemahkanolehYudiSantoso (2008) Yogyakarta, PustakaPelajar.

[17] Gillin, J.L. danGillin, J.P, 1954, Cultural Sociology, New York, The Macmilan

[18] Hamzah, Andi. 1994. Azas-Azas HukumPidana, RinekaCipta, Jakarta.

[19] -------- 2001, BungaRampaiHukumPidanadan Acara Pidana , Jakarta: GhaliaIndonesia

[20] Harahap, M. Yahya. 2004. Pembahasan Permasalahan Penerapan KUHAP, Penyidikan Dan Penuntutan, Jakarta: SinarGrafika.

[21] Hardy, Malcolm \&Heyes, Steve. 1988. PengantarKonseling. Terjemahan OlehSoenardji. Jakarta: Erlangga.

[22] Hendra Winata. 2000. Bantuan HukumSuatuHakAsasiManusiaBukanBelasKasihan, Jakarta: Elex Media Komputindo.

[23] Henslin, James M. 2015. Essentials of Sociology. A Down to Earth Approach. USA: Pearson.

[24] Hedstrom, Peter. \& Peter Bearman. 2009. Analytical Sociology. New York: Oxford University Press.

[25] Hurlock, Elizabeth B. 2001. PsikologiPerkembanganSuatuPendekatansepanjangRentang Kehidupan. Jakarta: Erlangga.

[26] Ishomuddin. 2018. Japanese Women: Culture, Character and Philosophy of Life. Yogyakarta: PohonCahaya.

[27] -----------, 2019. ParadigmaPenelitian. Malang: PPS UMM. Hand Out.

[28] Millan, Mc. 2001.Reabilty and Validity in Qualitative Research, BaverlyHillls, Ch, Sage.

[29] Milles, B. Matthew \& Huberman, A.M. 1994. Qualitative Data Analysis. Second Edition. (TerjemahanTjetjepRohendiRohidi). London: Sage Publication.

[30] Miles, B. Mathew dan Huberman, A Michael, Saldana, Johny. 2014. Analisis Data Kualitatif. BukuSumberTentangmetode-MetodeBaru. Jakarta: UI Press.

[31] MokhammadNajih. 2008. PolitikHukumPidanaPascaReformasi, Malang: In-Trans Publishing.

[32] Moleong, L.J. 1995. MetodologiPenelitiankualitatif. Bandung: RemajaRosdakarya.

[33] Molm. Linda. D. 1997. Coercive Power in Social Change. USA: Cambridge University Press.

[34] Poernomo, Bambang. 1994. Asas-AsasHukumPidana, Jakarta: Ghalia Indonesia.

[35] Rakhmad, Jalaluddin. 2007. PsikologiKomunikasi.Bandung :Remajakarya.

[36] Ritzer, G. 2001. Explorations in Social Theory. India: Sage Publications.

[37] -------. 2008. Teori Sosiologi Dari Teori Sosiologi Klasik Sampai Perkembangan Mutakhir Teori Sosial Posmodern. Yogyakarta : Kreasi wacana

[38] -------. 2009. SosiologiIlmuPengetahuanBerparadigma Ganda, Jakarta, Raja Grafindo Persada.

[39] ---------. 2014. Teori Postmodern. (Terjemahan Muhammad Taufik). Yogyakarta: Kreasi Wacana Offset.

[40] Soekanto, Serjono. 2018. Faktor-Faktor YangMemepengaruhiPenegakanHukum. Depok: PT RajagrafindoPersada.

[41] Stoley, Kathy S. 2005. The Basic of Sociology. USA: Greenword.

[42] Strauss, Anselm \& Corbin, Juliet. 2017. Dasar-Dasar Penelitian Kualitatif. Tata Langkah danTeknikTeknikTeoritisasi Data. Cetakan V. (TerjemahanShodiqdan Imam Muttaqien). Yogyakarta: PustakaPelajar.

[43] Supriadi. 2014. EtikadanTanggungJawabProfesiHukum Di Indonesia, SinarGrafika, Jakarta.

[44] Wahid, Abdul danMoh. Muhibbin. 2009. EtikaProfesi Hukum Rekonstruksi Citra Peradilan Di Indonesia, Malang: Bayumedia Publishing,

[45] Weber, M, 2006, Studi Komprehensif Sosiologi Kebudayaan, diterjemahkan dari buku Essaysfrom Max Weber, penerjemah : Abdul Qodir Shaleh, Yogyakarta, IRCiSoD

International Journal of Humanities Social Sciences and Education (IJHSSE) 
The Meaning of Prosocial Action for Activists of Legal Assistance Organizations (OBH) in Poor Communities in the City of Palangka Raya

[46] Winata, Hendra. 2000. Bantuan Hukum Suatu HakAsasi Manusia Bukan Belas Kasihan, Jakarta: Elex Media Komputindo.

\section{AUTHORS' BIOGRAPHY}

Laila Rahmawati, is a Doctor of Social Sciences and Politics at the University of Muhammadiyah Malang. In addition he is an employee at the Ministry of Law and Human Rights in Palangka Raya.
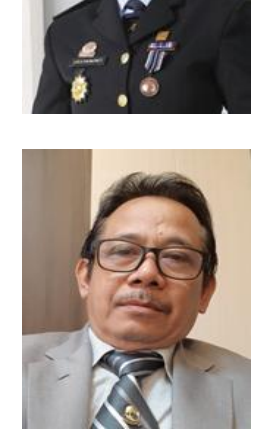

Ishomuddin, is Professor of Sociology of Islamic Society at the Muhammadiyah University of Malang. He has written many books and he is an visiting professor at several universities in Asian countries

Citation: Ishomuddin, et.al. "The Meaning of Prosocial Action for Activists of Legal Assistance Organizations $(\mathrm{OBH})$ in Poor Communities in the City of Palangka Raya" International Journal of Humanities Social Sciences and Education (IJHSSE), vol 7, no. 7, 2020, pp. 1-10. doi: http://dx.doi.org/10.20431/23490381.0707001 .

Copyright: () 2020 Authors. This is an open-access article distributed under the terms of the Creative Commons Attribution License, which permits unrestricted use, distribution, and reproduction in any medium, provided the original author and source are credited. 